\title{
PENGARUH VARIABEL MODERATOR PEMBERDAYAAN DAN PENDAYAGUNAAN ZAKAT DALAM MENANGGULANGI KEMISKINAN
}

\author{
Joko Hadi Purnomo \\ IAI Al Hikmah Tuban \\ Joko.hpurnomo@gmail.com
}

\begin{abstract}
The research objective was to determine the effect of zakat empowerment on poverty alleviation, the effect of zakat management on zakat empowerment, zakat management through zakat empowerment on poverty reduction, zakat management on zakat utilization, the effect of zakat utilization on the prevention. poverty, the effect of zakat management through the utilization of zakat on poverty reduction. The approach of this research is a mix method. The research procedure, in the first stage, uses a quantitative method. the second stage uses qualitative methods. The quantitative method uses Structural Equation Model-Partial Least Square analysis. Meanwhile, qualitative analysis uses interactive analysis. The research results prove that: zakat empowerment affects poverty alleviation in East Java Province; Management of zakat affects the empowerment of zakat; Management of zakat through the utilization of zakat has an effect on poverty alleviation; Zakat management has an effect on the utilization of zakat. The Zakat Economic Empowerment Program is proven to be able to turn the mustahiq /poor into muzaqi.
\end{abstract}

Keywords: Zakat Management, Poverty Alleviation.

\begin{abstract}
Abstrak: Tujuan penelitian adalah untuk mengetahui pengaruh pemberdayaan zakat terhadap penanggulangan kemiskinan, pengaruh pengelolaan zakat terhadap pemberdayaan zakat, pengelolaan zakat melalui pemberdayaan zakat terhadap penanggulangan kemiskinan, pengelolaan zakat terhadap pendayagunaan zakat, pengaruh pendayagunaan zakat terhadap penanggulangan kemiskinan, pengaruh pengelolaan zakat melalui pendayagunaan zakat terhadap penanggulangan kemiskinan. Pendekatan penelitian ini adalah mix method. Prosedur penelitian, pada tahap pertama menggunakan metode kauntitatif. Tahap kedua menggunakan metode kualatitatif. Metode kuantatif menggunakan analisa Structural Equation Model- Partial Least Square. Sedangkan analisa kualitatif menggunakan analisa interaktif. Hasil penelitian membuktikan bahwa: pemberdayaan zakat berpengaruh terhadap pengentasan kemiskinan di Propinsi Jawa Timur; Pengelolaan zakat berpengaruh terhadap pemberdayaaan zakat; Pengelolaan zakat melalui pendayagunaan zakat berpengaruh terhadap pengentasan kemiskinan; Pengelolaan zakat berpengaruh terhadap pendayagunaan zakat. Program Pemberdayaan Ekonomi Zakat terbukti mampu menjadikan mustahiq/fakir miskin menjadi muzaqi.
\end{abstract}

Kata Kunci: Pengelolaan Zakat, Penanggulangan Kemiskinan.

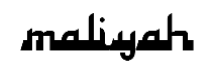

Jurnal Hukum Bisnis Islam

Volume 9 Nomor 2, Desember 2019

p-ISSN: 2088-4869/ e-ISSN: 2597-4351 


\section{Pendahuluan}

Salah satu masalah yang dihadapi pemerintah dalam pembangunan adalah adanya kesenjangan yang terdapat pada distribusi pendapatan. Konsentrasi penumpukan harta pada sekelompok orang merupakan kejahatan ekonomi yang menghambat sektor produksi, konsumsi, perdagangan, sirkulasi dan distrubusi kekayaan dan laju roda perekonomian. Kondisi tersebut menghalangi pelaku ekonomi memiliki akses yang bebas dan sama dalam mengambil manfaat dari sumbersumber alam, akan mencegah munculnya tindakan monopoli maupun oligopoli dalam aktivitas perekonomian karena hal tersebut merupakan antitesa dari adanya distribusi kekayaan secara adil. Islam menentang tindakan konsentrasi kekayaan dan menetapkan beberapa kebijakan untuk meminimalkan dan menjelaskan betapa pentingnya peran nilai dan moral dalam pembangunan ekonomi Islam. Pelarangan riba, monopoli, penimbunan, perampasan hak, dan lain-lain merupakan beberapa intrumen kebijakan yang diharapkan sanggup menekan konsentrasi dan penimbunan harta menuju distribusi kekayaan yang merata. Konsentrasi kekayaan menyebabkan ketimpangan pendapatan dan kesejahteraan, sehingga jumlah angka kemiskinan meningkat. ${ }^{1}$

Salah satu instrumen distribusi pendapatan adalah zakat. Zakat merupakan salah satu mekanisme pengentasan kemiskinan dalam Islam dengan membantu golongan fakir miskin. ${ }^{2}$ Zakat merupakan salah satu instrumen distribusi. Artinya, ada penyaluran sesuatu kepada orang atau pihak lain. ${ }^{3}$ Zarqa mengemukakan bahwa, definisi distribusi ialah transfer dari pendapatan kekayaan antara individu dengan cara

\footnotetext{
1 Tajuddin Pogo, Distribusi Kekayaan Individu Dalam Ekonomi Islam, (Tesis UIN Syarif Hidayatullah, 2010). 89

${ }^{2}$ Noor Syafinas Binti Muda, Keberkesanan Tagihan Zakat Kepada Asnaf Fakir Dan Miskin : Kajian Kes Bantuan Jayadiri, Jabatan Zakat Negeri Kedah, Ogos, 2014.

${ }^{3}$ Muhammad Abdullah Mannan, Teori Dan Praktik Ekonomi Islam (Yogyakarta: PT. Dana Bhakti Wakaf, 1995).113
} 
pertukaran (melalui pasar) atau dengan cara yang lain, seperti warisan, shadaqah, wakaf dan zakat. Zarqa mengatakan ada bebarapa faktor yang menjadi dasar redistribusi, yaitu: tukar menukar, kebutuhan, kekuasaa, sistem sosial dan nilai etika. Sejalan dengan sistem pertukaran, seseorang memeroleh pendapatan yang wajar dan adil sesuai dengan kinerja dan konstribusi yang diberikan. ${ }^{4}$

Indonesia merupakan negara dengan penduduk muslim terbesar di dunia. Menurut catatan The Pew Forum on Religion \& Public pada Tahun 2010 penduduk Islam di Indonesia mencapai $12,7 \%$ dari populasi dunia. Jumlah penduduk Indonesia pada tahun 2010 mencapai 237.641.236, dengan jumlah penduduk beragama Islam sebesar $88,1 \%$, atau 209.361.929 jiwa. $^{5}$

Di satu sisi jumlah penduduk miskin Indonesia berdasarkan pendataan BPS Tahun 2014 mencapai 22.961.847 jiwa atau setara $10,96 \% .^{6}$ Jika mengacu pada persentase jumlah penduduk Islam di Indonesia pada tahun 2010 88,1\% linier dengan jumlah angka kemiskinan, terdapat penduduk miskin yang beragama Islam sebanyak 20.252.375 jiwa. Adapaun jumlah penduduk di Provinsi Jawa Timur berdasarkan data BPS Tahun 2014 sebanyak 39.107.095 jiwa, untul lebih rincinya dapat dilihat pada tabel 1 di bawah ini.

Tabel 1

Jumlah penduduk, jumlah penduduk muslim, dan jumlah penduduk miskin di Jawa Timur

Sumber data: BPS Jatim dioalah

\footnotetext{
${ }^{4}$ Taqiyuddin Nabani, Al Nidlam Al Iqtishadi Fi Al Islam Islam (Membangun Sistem Ekonomi Altematif: Perspektif Islam), Terj. Maghfur Wahid (Surabaya: Risalah Gusti, 1999). 166

${ }^{5}$ Republika.co.id, "Inilah 10 Negara Dengan Populasi Muslim Terbesar Di Dunia," http://m.republika.co.id/berita/dunia-islam/islamnusantara/15/05/27/nowyh5-inilah-10-negara-dengan-populasi-muslim-terbesardi-dunia,. 27 Mei 2015 Pukul 06.16 WIB

${ }^{6}$ Badan pusat statistik, “Jumlah Dan Presentase Penduduk Miskin, Garis Kemiskinan, Indeks Kedalaman Kemiskinan (P1) Indeks Keparahan Kemiskinan (P2) Menurut Provinsi," http://www.bps.go.id/linkTabelStatis/view/id/1488.
} 
Pengaruh Variabel Moderator Pemberdayaan Dan Pendayagunaan Zakat ...

\begin{tabular}{|c|c|c|c|c|c|c|c|}
\hline \multirow[b]{2}{*}{$\begin{array}{l}\mathbf{N} \\
\mathbf{0}\end{array}$} & \multirow[b]{2}{*}{$\begin{array}{c}\text { Th } \\
\text { n }\end{array}$} & \multirow{2}{*}{$\begin{array}{l}\begin{array}{c}\text { Pendu } \\
\text { duk }^{7}\end{array} \\
\text { (jiwa) }\end{array}$} & \multicolumn{2}{|c|}{ Penduduk Muslim8 } & \multicolumn{3}{|c|}{ Penduduk Miskin 9} \\
\hline & & & (jiwa) & $\begin{array}{c}(\% \\
\text { terhadap } \\
\text { penduduk) }\end{array}$ & (jiwa) & $\begin{array}{c}\text { (\% } \\
\text { terhadap } \\
\text { penduduk) }\end{array}$ & $\begin{array}{c}\text { (\%) } \\
\text { terhadap } \\
\text { muslim) }\end{array}$ \\
\hline 1 & $\begin{array}{l}20 \\
11\end{array}$ & $\begin{array}{l}40.90 \\
3.400 \\
\end{array}$ & $\begin{array}{c}37.819 . \\
853\end{array}$ & $92,46 \%$ & $\begin{array}{c}5.665 .1 \\
21\end{array}$ & $13,85 \%$ & $14,98 \%$ \\
\hline 2 & $\begin{array}{l}20 \\
12\end{array}$ & $\begin{array}{l}42.14 \\
4.729\end{array}$ & $\begin{array}{c}39.657 . \\
788\end{array}$ & $94,10 \%$ & $\begin{array}{c}5.187 .2 \\
39\end{array}$ & $12,31 \%$ & $13,08 \%$ \\
\hline 3 & $\begin{array}{l}20 \\
13 \\
\end{array}$ & $\begin{array}{l}38.21 \\
4.245 \\
\end{array}$ & $\begin{array}{c}36.779 . \\
503\end{array}$ & $96,25 \%$ & $\begin{array}{c}4.682 .0 \\
31\end{array}$ & $12,25 \%$ & $12,73 \%$ \\
\hline 4 & $\begin{array}{l}20 \\
14 \\
\end{array}$ & $\begin{array}{l}39.10 \\
7.095 \\
\end{array}$ & $\begin{array}{c}37.683 . \\
597\end{array}$ & $96,36 \%$ & $\begin{array}{c}4.802 .3 \\
51 \\
\end{array}$ & $12,28 \%$ & $12,74 \%$ \\
\hline
\end{tabular}

Tabel 1 di atas menggambarkan rata-rata penduduk muslim di Provinsi Jawa Timur selama 4 (empat) tahun dengan jumlah rata-rata $94,79 \%$ dari total penduduk atau di atas ratarata nasional penduduk beragama Islam. Sedangkan jumlah penduduk miskin di Provinsi Jawa Timur pada tahun 2014 sebanyak $12.28 \%$ atau 4.802 .351 jiwa, dengan prosentase penduduk beragama Islam di Provinsi Jawa Timur 94,79\%, maka dapat diketahui jumlah penduduk miskin yang beragama Islam sebanyak 4.552.149 jiwa. Fenomena tersebut menggambarkan bahwa jumlah penduduk miskin di Provinsi Jawa Timur yang beragama Islam masih cukup tinggi. Namun demikian, dari data BPS tersebut pula dapat diketahui potensi zakat di Provinsi Jawa Timur, karena terdapat jumlah penduduk yang tidak masuk kategori miskin 94,27\% penduduk. Sedangkan orang yang tidak dikategorikan miskin berjumlah 27.048.000.

\footnotetext{
${ }^{7}$ Badan pusat statistik, "Kependudukan,” BPS Jatim.2014

${ }^{8}$ Badan pusat statistik, "Data Penduduk Muslim," Kemenag Jatim.2014

${ }^{9}$ Badan pusat statistik, “Jumlah Dan Presentase Penduduk Miskin, Garis

Kemiskinan, Indeks Kedalaman Kemiskinan (P1) Indeks Keparahan Kemiskinan (P2) Menurut Provinsi."2014
} 
Dengan asumsi, anak belum baligh sekitar $25 \%$ (dua puluh lima persen) atau kurang lebih 6.087.000 jiwa, orang mukallaf zakat (wajib berzakat) adalah 20.061.000 juta. Jika setiap orang dikenakan zakat 2,5 kg (dua setengah kilo gram) beras dengan harga Rp8.300/kg, berarti dana yang terkumpul dalam sekali momentum zakat fitrah adalah 20.061 .000 juta $\mathrm{x}$ Rp 20.700 atau sebesar Rp416.265.750.000. Ini baru potensi zakat fitrah saja.

Potensi itu belum termasuk dengan zakat maal maupun dana-ibadah sosial lainnya yang tentunya semakin berlipat ganda. ${ }^{10}$ Besarnya nilai potensi zakat tersebut sejalan dengan hasil penelitian BAZNAS, yang mana bahwa di Indonesia terdapat potensi zakat mencapai Rp. 217.000.000.000.000, namun potensi tersebut belum banyak yang terserap, karena potensi yang terserap dan dikelola oleh lembaga amil zakat sebesar Rp 2.730.000.000.000 atau hanya sekitar $1 \% .{ }^{11}$ Secara nasional potensi zakat lengkap dapat dilihat seperti tabel di bawah ini :

Tabel 2

Potensi zakat nasional ${ }^{12}$

Sumber data: Abdulloh Mubarok, "Penghimpunan Dana Zakat Nasional"

\begin{tabular}{|l|l|r|}
\hline No & Tahun & $\begin{array}{c}\text { Potensi Zakat } \\
\text { (Rp. Dalam Jutaan) }\end{array}$ \\
\hline 1 & Tahun 2011 & 1.730 .000 \\
\hline 2 & Tahun 2012 & 2.200 .000 \\
\hline 3 & Tahun 2013 & 2.800 .000 \\
\hline 4 & Tahun 2014 & 3.300 .000 \\
\hline
\end{tabular}

\footnotetext{
${ }^{10}$ Badan pusat statistik, "Zakat Indonesia Yang Terhimpun Baru Satu Persen Dari Potensi,"

http://www.nasional.kompas.com/read/2016/07/02/10000301/zakat.indonesia.ya ng.terhimpun.baru.satu.persen.dari.potensi. 02 Juli 2013

${ }^{11}$ Nidia Zuraya, "Potensi Zakat Rp 217 Triliun Terserap Satu Persen," http://www.republika.co.id/berita/ekonomi/syariah-ekonomi/13/04/29/mm039ypotensi-zakat-rp-217-triliun-terserap-satu-persen. 29 April 2013

12 Abdullah Mubarok and Baihaqi Fanani, "Penghimpunan Dana Zakat Nasional (Potensi, Realisasi Dan Peran Penting Organisasi Pengelola Zakat)" (n.d.).9
} 
Dengan potensi yang sangat besar, zakat merupakan salah instrumen nasional untuk turut membantu pencapaian sasaran pembangunan nasional khususnya dalam mengentaskan kemiskinan. Dana zakat sebagai sumber pendanaan program penanggulangan kemiskinan harus dikelola, didayagunakan dan diberdayakan untuk meningkatkan taraf hidup masyarakat. Sehingga dalam perencanaan anggaran, zakat dapat digunakan sebagai sumber pembiayaan. ${ }^{13}$ Sebagaimana hasil penelitian Bagong Suyanto dkk tentang Model Pengentasan Kemiskinan: Melalui Peran Serta Masyarakat Mampu di Pronvinsi Jawa Timur, dengan mengambil sampel 200 masyarakat mampu di 3 (tiga) kota di Jatim (Tuban, Nganjuk, serta Jember) menemukan bahwa bentuk amal yang biasa dilakukan oleh masyarakat mampu adalah selalu membayar zakat (81\%), infaq (42\%), serta sedekah (28\%). Sedangkan waktu mendonasikan dana kepada masyarakat miskin adalah selalu pada bulan Ramadhan (60 \%), Idul qurban (18,5\%), serta hari raya keagamaan lainnya $(37,5$ $\%) .{ }^{14}$

Zakat memiliki peran penting dalam mengurangi kesenjangan, sebagimana dinyatakan oleh Ketua Badan Amil Zakat Nasional (Baznas) Bambang Sudibyo, "Zakat berperan penting untuk atasi kesenjangan yang ditunjukkan angka gini. Pada 2014 sebesar 0,40, kemudian naik menjadi 0,42, namun turun 0,40 . Jika zakat, infaq, dan sedekah dikelola dengan baik, insya Allah kesenjangan bisa turun," tutupnya. ${ }^{15}$

Zakat sebagai salah satu instrumen fundamental untuk pengurangan kesenjangan pendapatan sangat dipengaruhi

\footnotetext{
${ }^{13}$ Badan Kebijakan Fiskal Pusat Kebijakan Ekonomi Makro Kementerian Keuangan Republik Indonesia, Laporan Kajian Islamic Public Finance (Jakarta: Kementerian Keuangan Republik Indonesia, 2012).76

${ }^{14}$ Untung Dwiharjo, "Menguak Potensi Zakat Di Jawa Timur," http://www.ydsf.org/blog/menguak-potensi-zakat-di-jawa-timur. 13 Januari 2017. 11.22

${ }^{15}$ Untung Dwiharjo, "Potensi Zakat Di Indonesia Sangat Besar," http://www.ksp.go.id/potensi-zakat-di-indonesia-sangat-besar/.30 Juni 2006,1
} 
faktor-faktor pendukung untuk mencapai tujuan pengurangan kemiskinan. Dintaranya faktor jumlah zakat yang diterima mustahiq berpengaruh kepada peningkatan pendapatannya, dimana semakin besar dana zakat yang disalurkan meningkatkan pendapatan mustahiq. ${ }^{16}$ Namun hasil penelitian lain menghasil faktor-faktor berbeda dengan temuan penelitan sebelumnya. Faktor-faktor yang berpengaruh kepada pengurangan kemiskinan temuan penelitian Mira Sartika, diantaranya pembinaan kepada mustahiq, pengawasan penggunaan dana oleh mustahiq, dan alokasi pendayagunaan zakat terhadap pendapatan. ${ }^{17}$ Dari hasil penelitian tersebut memunculkan pertanyaan baru, diantaranya bagaimana pembinaan LAZ kepada mustahiq? Apa bentuk pembinaan dan pengawasan yang diberikan LAZ kepada mustahiq? Berapa lama pembinaan dan pengawasan LAZ kepada mustahiq?

Dalam kerangka pengurangan kemiskinan, dana zakat dipergunakan untuk pemberdayaan masyarakat. Temuan tersebut dalam penelitiaannya dengan judul Sistem pengelolaan zakat LAZ Rumah Zakat kota Semarang, sudah cukup baik, hal ini dapat dibuktikan dari usaha pengumpulan dana, pendistribusiannya maupun pendayagunaan zakat yang mana diharapkan dalam kurun waktu tiga tahun para mustahiq (penerima zakat) dapat berubah menjadi muzakki (pemberi zakat). ${ }^{18}$ Temuan lainnya bahwa faktor pemberdayaan zakat signifikan berpengaruh terhadap pengentasan kemiskinan, penelitian di LAZ Yayasan Solo Peduli Surakarta. Hasil penelitian menunjukkan adanya pengaruh yang signifikan antara pemberdayaan zakat dengan pendapatan mustahiq. Pemberdayaan diindikasikan dari jumlah dana yang disalurkan

\footnotetext{
${ }^{16}$ Mila Sartika, "Pengaruh Pendayagunaan Zakat Produktif Terhadap Pemberdayaan Mustahiq Pada LAZ Yayasan Solo Peduli Surakarta," Jurnal Ekonomi Islam La Riba Vol.II No. (2008): 87.

${ }^{17}$ Nadiya Analisa, "Pengaruh Pendayagunaan Zakat Produktif Terhadap Pendapatan Mustahiq (Studi Kasus Pada LAZ PKPU Cabang Surabaya)" (UIN Walisongo Semarang, 2015). 9-18

${ }^{18}$ Saifulloh, "Pengelolaan Zakat Dalam Pemberdayaan Masyarakat (Studi Pada LAZ Rumah Zakat Kota Semarang)" (UIN Walisongo Semarang, 2014).12
} 
LAZ Yayasan Solo Peduli Surakarta mustahiq. Ini berarti bahwa jumlah dana (zakat) yang disalurkan benar-benar mempengaruhi pendapatan mustahiq, dengan kata lain semakin tinggi dana yang disalurkan maka akan semakin tinggi pula pendapatan mustahiq. Variabel jumlah dana (zakat) yang disalurkan dan variabel pendapatan mustahiq ditemukan besarnya pengaruh variabel jumlah dana (zakat) yang disalurkan terhadap pendapatan mustahiq sebesar 10,2 \%. yang berarti sebesar $89,8 \%$ dari pendapatan mustahiq dipengaruhi oleh faktor lain. ${ }^{19}$

Pengurangan kemiskinan dalam menggunakan dana zakat tidak lepas dari faktor pengelolaan. Indikasi yang ditemukan dalam dari penelitiannya sebelumnya dari Agustina yang dilakukan di Kota Jambi ${ }^{20}$ bahwa jumlah anggota keluarga mustahiq, usia mustahiq, dan tingkat pendidikan mustahiq secara mandiri mempengaruhi keberhasilan pengelolaan, namun dalam penelitian tersebut belum pengaruh indikator pengelolaan terhadap pengentasan kemiskinan, sehingga memunculkan pertanyaan apakah indikator jumlah anggota keluarga mustahiq, usia mustahiq, dan tingkat pendidikan mustahiq terhadap pengentasan kemiskinan? Indikator mana yang paling berpengeruh dalam pengentasan kemiskinan? Apakan indikator pengelolaan berpengaruh terhadap pemberdayaan masyarakat.

Faktor lain yang mempegaruhi pengurangan kemiskinan melalui dana zakat adalah faktor pendayagunaan. Faktor pendayagunaan zakat mencakup, pertanyaan-pertanyaan apakah zakat dipergunakan untuk mendukung usaha mustahiq? Apakah zakat dipergunakan untuk memberikan pelatihan kewirausahaan? Apakah zakat dipergunakan untuk asitensi

\footnotetext{
${ }^{19}$ Sartika, "Pengaruh Pendayagunaan Zakat Produktif Terhadap Pemberdayaan Mustahiq Pada LAZ Yayasan Solo Peduli Surakarta."20

${ }^{20}$ Agustina Mutia and Anzu Elvira Zahara, "Analisis Faktor-Faktor Yang Mempengaruhi Kesejahteraan Ekonomi Mustahiq Melalui Pemberdayaan Zakat (Studi Kasus PenyaluranZakat Produktif/ Modal Usaha Pada Bazda Kota Jambi)," Kontekstualita Vol.25 No. (n.d.): 11.
}

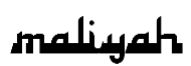

Jurnal Hukum Bisnis Islam 
tindak lanjut? Apakah pengelola zakat telah bekerjasama dengan pihak-pihak yang juga melakukan upaya penanggulangan kemiskinan.

Pendayagunaan zakat sebagai salah satu kunci penting dalam pengentasan kemiskinan, hal ini diketahui dari penelitian bahwa faktor yang mempengaruhi keberhasilan zakat produktif dalam mengurangi angka kemiskinan adalah pengumpulan dana, pendistribusian, pendayagunaan. Dana zakat yang telah dihimpun oleh lembaga amil zakat disalurkan kepada mustahiq dengan pendekatan pemberdayaan masyarakat dengan menggunakan 2 (dua) model. Pertama distribusi konsumtif yaitu pendistribusian zakat, infaq dan shodaqah yang pemanfaatannya langsung digunakan oleh mustahiq dan habis dalam jangka pendek serta pendayagunaannya tidak menimbulkan pengaruh secara ekonomi dan pemberdayaan mustahiq, model ini dibagi menjadi dua model yaitu model distribusi konsumtif tradisional dan model konsumtif kreatif. Kedua, model distribusi produktif yaitu pendistribusian zakat, infaq dan shodaqah yang pemanfaatannya tidak langsung habis serta pendayagunaannya menimbulkan pengaruh secara ekonomi dan pemberdayaan mustahiq. Model ini hanya berupa model distribusi produktif kreatif 21 Pemberian Zakat produktif dalam bentuk modal usaha berdampak positif bagi peningkatan pendapatan masyarakat penerima zakat produktif. Sebagai contoh pemberian zakat produktif dalam bentuk modal usaha memberikan pengaruh positif terhadap kenaikan pendapatan usaha masyarakat. Meningkatnya pendapatan usaha penerima zakat produktif dalam bentuk modal usaha berdampak kepada berkurangnya jumlah angka kemiskinan di Kabupaten Aceh Utara. ${ }^{22}$ Hal itu didukung hasil penelitian sebelumnya, ... this

\footnotetext{
${ }^{21}$ Saifulloh, "Pengelolaan Zakat Dalam Pemberdayaan Masyarakat (Studi Pada LAZ Rumah Zakat Kota Semarang)."16

22 Rusli, “Analisis Dampak Pemberian Modal Zakat Produktif Terhadap Pengentasan Kemiskinan Di Kabupatenaceh Utara," Jurnal Ilmu Ekonomi ISSN 2302-, no. Pascasarjana Universitas Syiah Kuala 8 Pages pp (n.d.): 56-63.
} 
study proposed that JZNK should give a sufficient amount of capital for the asnaf to support their business needs, provide entrepreneurialship training and guidance, follow-up assistance, active monitoring, and establishing cooperation between JZNK with other anti-poverty agency, so that the effectiveness of the program can be enhanced. ${ }^{23}$

Objek penelitian ini pada Lembaga Amil Zakat Infaq Sodaqoh (LAZIS) Yayasan Dana Sosial Al falah (YDSF) menjadi lokasi penelitian karena mempunyai Visi pemberdayaan yang berbasis pada sistem berkeadilan, selain itu juga Yayasan Dana Sosil Al falah (YDSF) juga mempunyai tanggung jawab atas kaum Dhuafa yang ada di wilayah Jawa Timur. Tanggun jawab tersesebut sejalan dengan tujuan didirikannnya YDSF sebagai salah satu lembaga yang mengurus dana zakat untuk disalurkan kepada para mustahiq. Faktor yang menentukan peniliti memilih YDSF sebagai objek penelitian karena telah membagi program-programnya dalam kategori yang jelas dan mudah difahami oleh khalayak ramai dalam penyalurannya, misalnya di bidang ekonomi ada program warung berdaya dan kambing berdaya. Yang menarik juga adalah YDSF dalam menggalang dana telah melakukan jemput zakat. YDSF memiliki informasi yang mudah diakses melalui websitenya, sehingga untuk mendapatkan informasi kegiatan-kegiatannya dapat dipantau real time. Alasan terakhir karena cakupan wilayah kerja YDSF sangat luas di seluruh Indonesia umumnya dan di Provinsi Jawa Timur khususnya Maka dari alasan tersebut peniliti menjadikan YDSF sebagai objek penelitian.

Dengan adanya femonena-fenomena, data, dan hasil temuan penelitian sebelumnya, penelitian ini berfokus pada pengaruh Pengelolaan Zakat Terhadap Penanggulanan Kemiskinan Dengan Pemberdayaan Zakat Dan Pendayagunaan Zakat Sebagai Variabel Moderating [Studi di Yayasan Sosial Dana Al Falah (YDSF) Propinsi Jawa Timur]. Berdasarkan fokus

${ }^{23}$ Muda, Keberkesanan Tagihan Zakat Kepada Asnaf Fakir Dan Miskin : Kajian Kes Bantuan Jayadiri, Jabatan Zakat Negeri Kedah. 18 
tersebut, penelitian ini memiliki tujuh tujuan penelitian, yaitu: 1) Untuk mengetahui dan menganalisa pengaruh pemberdayaan zakat terhadap penanggulangan kemiskinan. 2) Untuk mengetahui dan menganalisa pengaruh pengelolaan zakat terhadap pemberdayaan zakat. 3) Untuk mengetahui dan menganalisa pengaruh pengaruh pengelolaan zakat melalui pemberdayaan zakat terhadap penanggulangan kemiskinan.4) Untuk mengetahui dan menganalisa pengaruh pengelolaan zakat terhadap pendayagunaan zakat. 5) Untuk mengetahui dan menganalisa pengaruh pendayagunaan zakat terhadap penanggulangan kemiskinan. 6) Untuk mengetahui dan menganalisa pengaruh pengelolaan zakat melalui pendayagunaan zakat terhadap penanggulangan kemiskinan. 7) Untuk mengetahui dan menganalisa pengelolaan Program Pemberdayaan Ekonomi Kota.

\section{Metode Penelitian}

Penelitian ini menggunakan pendekatan metode campuran sequential explanatory (urutan pembuktian). ${ }^{24}$ Pada tahap pertama, metode kuantitif digunakan untuk mengetahui hubungan antar variabel. Adapun variabel yang dianalisa adalah variabel pengelolaan zakat, pemberdayaan zakat, pendayagunaan zakat dan pengentasan kemiskinan. Analisa data yang digunakan untuk penelitian kuantitatif menggunakan Structural Equation Model- Partial Least Square (SEM-PLS). Pada tahap kedua, penelitian ini menggunakan pendekatan kualitatif, dimana setalah diketahui hasil dari pembuktian kuantitatif dilakukan pendalaman terhadap hubunganhubungan antar variabel penelitian, dengan melihat pengalaman pelaksanaan pengelolaan program pemberdayaan ekonomi kota.

Jenis data yang digunakan dalam penelitian ini adalah data primer dan data sekunder. Data primer diperoleh diambil dari objek dan subjek penelitian. Sedangkan data sekunder

\footnotetext{
${ }^{24}$ Sugiyo, Metode Penelitian Kombinasi (Mix Methods) (Bandung: Alfabeta, 2017). 401
} 
diperoleh dari dokumen laporanYDSF, dokumen catatan, dan data-data lain yang relevan dalam penelitian ini yang dikeluarkan YDSF. Data primer yang bersumber dari objek penelitian diperoleh melalui penyebaran kuisioner kepada responden, sedangkan data primer yang bersumber dari subjek penelitian diperoleh melalui indept interview dan Observasi kepada penerima pengurus dan staf YDSF serta muzaki YDSF. Objek dan subjek penelitian tesis ini adalah di YDSF. Populasi penilitian adalah seluruh pengurus dan staf YDSF. Sampel penelitian adalah seluruh populasi penelitian. Hal itu disebabkan populasi penelitian ini kecil, sehingga memungkinkan untuk populasi dijadikan sampel. Pengambilan subjek penelitan dengan pendekatan kualitatif, diambil 5 informan pengurus dan staf YDSF, serta 3 orang informan muzaki YDSF.

\section{Analisis Data Kuantitatif}

\begin{tabular}{|c|c|c|c|}
\hline $\begin{array}{c}\text { Variabel } \\
\text { Laten }\end{array}$ & $\begin{array}{l}\text { Variabel } \\
\text { manifes }\end{array}$ & Indikator & Sumber data \\
\hline \multirow[t]{2}{*}{$\begin{array}{l}\text { Pemberd } \\
\text { ayaan } \\
\left(\xi_{1}\right)\end{array}$} & $\begin{array}{l}\text { Kenaikan } \\
\text { pendapat } \\
\text { an } \\
\text { keluarga } \\
\text { mustahiq } \\
\left(\mathrm{X}_{11}\right)\end{array}$ & $\begin{array}{l}\text { Jumlah rata-rata } \\
\text { kenaikan } \\
\text { pendapatan } \\
\text { keluarga mustahiq } \\
\left(\mathrm{X}_{111}\right)\end{array}$ & $\begin{array}{ll}\text { - } & \text { sekunder/ } \\
\text { YDSF/Diola } \\
\mathrm{h} \\
\text { - Indepth } \\
\text { intervew }\end{array}$ \\
\hline & $\begin{array}{l}\text { Jumlah } \\
\text { anggota } \\
\text { keluarga } \\
\text { mustahiq } \\
\left(\mathrm{X}_{12}\right)\end{array}$ & $\begin{array}{lr}\text { Jumlah rata-rata } \\
\text { anggota keluarga } \\
\text { mustahiq } \\
\text { mengalami } \\
\text { kenaikan } \\
\text { pendapatan }\left(\mathrm{X}_{121}\right)\end{array}$ & $\begin{array}{ll}\text { - } & \text { sekunder/ } \\
\text { YDSF/Diola } \\
\mathrm{h} \\
\text { - Indepth } \\
\text { intervew }\end{array}$ \\
\hline $\begin{array}{l}\text { Pengelol } \\
\text { aan } \\
\text { zakat } \\
\left(\xi_{2}\right),\end{array}$ & $\begin{array}{l}\text { Perencan } \\
\text { aan } \\
\text { program } \\
\left(\mathrm{X}_{21}\right)\end{array}$ & $\begin{array}{l}\text { Dilaksanakanny } \\
\text { a perencanaan } \\
\text { khusus program } \\
\text { dalam satuan } \\
\text { periode } \\
\text { program }\left(\mathrm{X}_{211}\right)\end{array}$ & $\begin{array}{ll}\text { - } & \text { sekunder/ } \\
\text { YDSF/Diola } \\
\mathrm{h} \\
\text { - Indepth } \\
\text { intervew }\end{array}$ \\
\hline
\end{tabular}




\begin{tabular}{|c|c|c|c|}
\hline & $\begin{array}{l}\text { Pengawa } \\
\text { san } \\
\text { kepada } \\
\text { Mustahiq } \\
\left(\mathrm{X}_{22}\right)\end{array}$ & $\begin{array}{ll}\text { waktu } & \\
\text { pengawasan } \\
\text { dalam satuan } \\
\text { bulan per } 6 \\
\text { (enam) bulan } \\
\left(\mathrm{X}_{221}\right) & \\
\end{array}$ & $\begin{array}{ll}\text { - } & \text { sekunder/ } \\
\text { YDSF/Diola } \\
\mathrm{h} \\
\text { - Indepth } \\
\text { intervew }\end{array}$ \\
\hline & $\begin{array}{l}\text { Evaluasi } \\
\left(\mathrm{X}_{23}\right)\end{array}$ & $\begin{array}{l}\text { Frekuensi } \\
\text { pelaksanaan } \\
\text { Evaluasi dalam } \\
\text { satuan bulan } \\
\text { per } 6 \text { (enam) } \\
\text { bulan }\left(\mathrm{X}_{131}\right)\end{array}$ & $\begin{array}{ll}\text { - } & \text { sekunder/ } \\
\text { YDSF/Diola } \\
\mathrm{h} \\
\text { - Indepth } \\
\text { intervew }\end{array}$ \\
\hline & $\begin{array}{l}\text { Pendamp } \\
\text { ingan } \\
\left(\mathrm{X}_{24}\right)\end{array}$ & $\begin{array}{l}\text { - Jumlah tenaga } \\
\text { pendamping } \\
\text { satuan orang } \\
\left(\mathrm{X}_{241}\right) \\
\\
\text { - Frekuensi } \\
\text { kehadiran } \\
\text { tenaga } \\
\text { pendamping } \\
\text { dalam satuan } \\
\text { kali per bulan } \\
\left(\mathrm{X}_{242}\right)\end{array}$ & 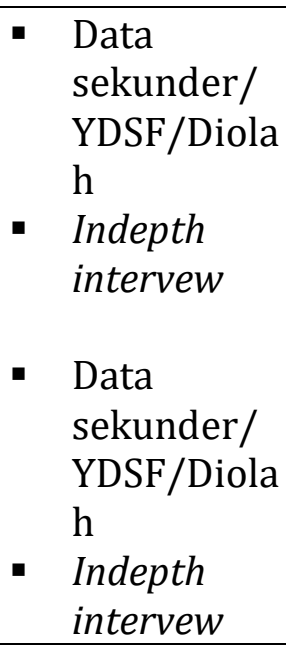 \\
\hline $\begin{array}{l}\text { Pendaya } \\
\text { gunaan } \\
\text { zakat } \\
\left(\xi_{3}\right)\end{array}$ & $\begin{array}{l}\text { Pendaya } \\
\text { gunaan } \\
\text { produktif } \\
\text { kreatif } \\
\left(\mathrm{X}_{31}\right)\end{array}$ & $\begin{array}{ll}\text { - Jumlah } & \text { Modal } \\
\text { kerja dalam } & \text { satuan rupiah } \\
& \left(\mathrm{X}_{311}\right) \\
\text { - } & \text { Sarana } \\
& \text { dalam soduksi } \\
& \text { rupiah }\left(\mathrm{X}_{312}\right)\end{array}$ & $\begin{array}{ll}\text { - } & \text { Data } \\
\text { sekunder/ } \\
\text { YDSF/Diola } \\
\text { h } \\
\text { - } \\
\text { Data } \\
\text { sekunder/ } \\
\text { YDSF/Diola } \\
\text { h }\end{array}$ \\
\hline $\begin{array}{l}\text { Pengent } \\
\text { asan }\end{array}$ & $\begin{array}{l}\text { Indeks } \\
\text { Kedalam }\end{array}$ & $\begin{array}{l}\text { Indeks Kedalaman } \\
\text { Kemiskinan/Povert }\end{array}$ & $\begin{array}{l}\text { Data } \\
\text { sukender/BPS }\end{array}$ \\
\hline
\end{tabular}


Pengaruh Variabel Moderator Pemberdayaan Dan Pendayagunaan Zakat ...

\begin{tabular}{|c|c|c|c|}
\hline \multirow[t]{2}{*}{$\begin{array}{l}\text { kemiskin } \\
\text { an }(\eta)\end{array}$} & \begin{tabular}{|l|} 
an \\
Kemiskin \\
an/Pover \\
ty Gap \\
Index-P1 \\
$\left(\mathrm{Y}_{11}\right)$ \\
\end{tabular} & y Gap Index-P1 ( $\left.\mathrm{Y}_{11}\right)$ & \\
\hline & \begin{tabular}{|l|} 
Indeks \\
Keparah \\
an \\
Kemiskin \\
an/Prove \\
$r$-ty \\
Severity \\
Index-P2 \\
$\left(\mathrm{Y}_{12}\right)$
\end{tabular} & $\begin{array}{l}\text { Indeks Keparahan } \\
\text { Kemiskinan/Prover } \\
\text {-ty Severity Index- } \\
\text { P2 }\left(\mathrm{Y}_{12}\right)\end{array}$ & $\begin{array}{l}\text { Data } \\
\text { Sekunder/BPS }\end{array}$ \\
\hline
\end{tabular}

Model struktural dalam penelitian ini disajikan dalam gambar di bawah ini.

Gambar 1.

Langkah-langkah kerangka model SEM-PLS

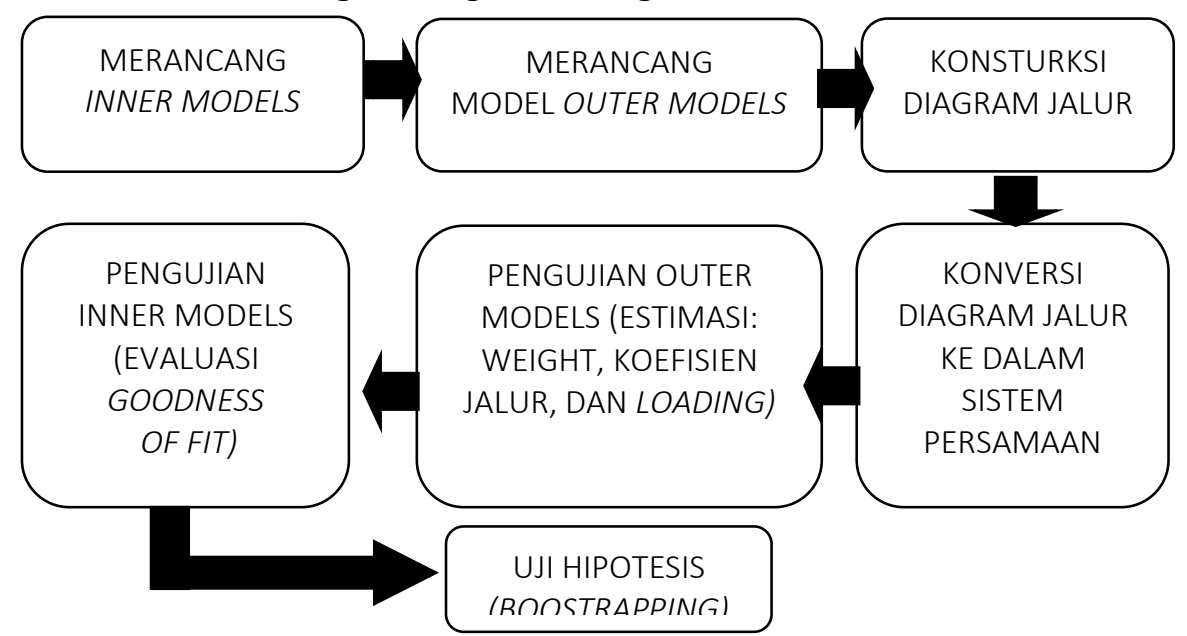

Sumber: Mahfudz Sholihin, "Analisis SEM-PLS dengan WrapPLS 3.0" disesuaikan

\section{Analisis Data Kualitatif}

Analisis data kualitatif ini menggunakan analisis interaktif (Miles danHuberman, 1984). Dalam model analisis 
ini, tiga komponen analisisnya yaitu reduksidata, sajian data, dan penarikan kesimpulan atau verivikasi, aktivitasnya dilakukandalam bentuk interaktif dengan proses pengumpulan data sebagai suatu proses yangberlanjut, berulang, dan terusmenerus hingga membentuk sebuah siklus. Secara skematis proses analisis interaktif ini dapat digambarkan sebagai berikut:

Gambar 2. Skema proses analisis interaktif

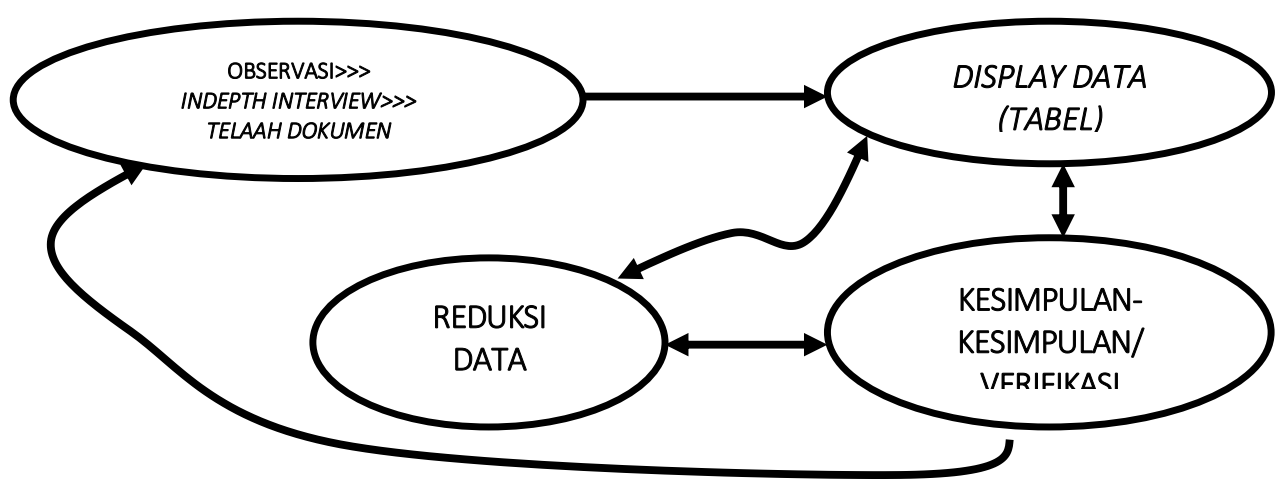

\section{Pembahasan dan Penilaian}

1. Menilai Outer model

a. Uji Validitas

1) Indikator reflektif

Uji validitas indikator reflektif menggunakan 3 (tiga) uji yaitu convergent validity, Discriminant validity dan Average Variance Extracted (AVE). Hasil pengujian pada penelitian ini sebagai berikut:

a) Convergent Validity.

Pengujian validitas konvergen menggunakan kriteria nilai loading setiap indikator $>0,5$ maka indikator variabel dinyatakan valid dengan mengabaikan tanda + (plus) atau - (minus), artinya tanda plus $(+)$ ataupun minus $(-)$ tidak mempengaruhi validitas pengujian.

Tabel 4

Nilai Outer Loading

\begin{tabular}{|c|c|c|}
\hline Variabel & Indikator & Outer Loadings \\
\hline Pengelolaan zakat & $\mathrm{X}_{211}$ & 0,827 \\
\hline
\end{tabular}


Pengaruh Variabel Moderator Pemberdayaan Dan Pendayagunaan Zakat ...

\begin{tabular}{|l|l|l|}
\hline \multirow{4}{*}{$\left.\mathrm{X}_{2}\right)$} & $\mathrm{X}_{221}$ & 0,859 \\
\cline { 2 - 3 } & $\mathrm{X}_{231}$ & 0,825 \\
\cline { 2 - 3 } & $\mathrm{X}_{241}$ & 0,834 \\
\cline { 2 - 3 } & $\mathrm{X}_{242}$ & 0,818 \\
\hline
\end{tabular}

Sumber: Perhitungan Smart PLS 3.0 Student Version

Menggunakan software Smart PLS 3.0 Student Version dihasilkan nilai outer loadings pada tabel 4 di atas. Prosedur penilaiannya dengan cara membandingkan loading dengan standar. Kriteria dinyatakan valid apabila loading lebih besar 0,500. Dengan melihat tabel 4, maka dapat dikatakan seluruh outer loading ( $\mathrm{X}_{211}$ : perencanaan khusus program, $\mathrm{X}_{221}$ : waktu pengawasan, $\mathrm{X}_{231}$ : frekuensi pelaksanaan evaluasi, $\mathrm{X}_{241}$ : jumlah tenaga pendamping, $\mathrm{X}_{251}$ : frekuensi kehadiran tenaga pendamping) berpengaruh terhadap variabel laten $\mathrm{X} 2$ (pengelolaan zakat).

b) Discriminant validity

Discriminant validity adalah nilai cross loading faktor yang berguna untuk mengetahui apakah konstruk memiliki diskriminan yang memadai.

Tabel 5

Nilai Cross Loadings

\begin{tabular}{|l|c|c|c|c|}
\hline Indikator & $\begin{array}{c}\mathrm{X}_{1} \\
\text { (Pemberda } \\
\text {-yaan } \\
\text { zakat) }\end{array}$ & $\begin{array}{c}\mathrm{X}_{2} \\
\text { (Pengelol } \\
\text { a-an } \\
\text { zakat) }\end{array}$ & $\begin{array}{c}\mathrm{X}_{3} \\
\text { (Penday } \\
\text { a- } \\
\text { gunaan } \\
\text { zakat) }\end{array}$ & $\begin{array}{c}\mathrm{Y} \\
\text { (Penang } \\
- \\
\text { gulanga } \\
\mathrm{n} \\
\text { Kemiski- } \\
\text { nan) }\end{array}$ \\
\hline $\mathrm{X}_{111}$ & 1,000 & $-0,833$ & 0,764 & $-0,963$ \\
\hline $\mathrm{X}_{121}$ & 0,840 & $-0,710$ & 0,629 & $-0,801$ \\
\hline $\mathrm{X}_{211}$ & $-0,818$ & 0,820 & $-0,720$ & 0,825 \\
\hline $\mathrm{X}_{221}$ & $-0,739$ & 0,859 & $-0,768$ & 0,687 \\
\hline $\mathrm{X}_{231}$ & $-0,502$ & 0,832 & $-0,820$ & 0,479 \\
\hline $\mathrm{X}_{241}$ & $-0,695$ & 0,840 & $-0,854$ & 0,654 \\
\hline
\end{tabular}




\begin{tabular}{|l|c|c|c|c|}
\hline$Y_{242}$ & $-0,694$ & 0,814 & $-0,741$ & 0,751 \\
\hline$X_{311}$ & 0,671 & $-0,747$ & 0,854 & 0,705 \\
\hline$X_{321}$ & 0,713 & $-0,925$ & 0,947 & $-0,660$ \\
\hline$Y_{111}$ & $-0,863$ & 0,702 & $-0,595$ & 0,895 \\
\hline$Y_{112}$ & $-0,939$ & 0,816 & $-0,759$ & 0,975 \\
\hline
\end{tabular}

Sumber: Smart PLS 3.0 Student Version

Nilai cross loading indikator $\mathrm{X}_{111}$ terhadap $\mathrm{X}_{1}$ sebesar 1,000; nilai cross loading $\mathrm{X}_{121}$ terhadap $\mathrm{X}_{1}$ sebesar 0,840 lebih besar nilai cross loading $\mathrm{X}_{111}$ terhadap $\mathrm{X}_{2}$ sebesar -0,833; nilai cross loading $\mathrm{X}_{121}$ terhadap $\mathrm{X}_{2}$ sebesar -.0710. Artinya indikator $\mathrm{X}_{111}$ (jumlah rata-rata kenaikan pendapatan keluarga mustahiq/fakir miskin) dan indikator $\mathrm{X}_{121}$ (jumlah rata-rata anggota keluarga mustahiq/fakir miskin yang mengalami kenaikan pendapatan) valid dan dapat menjelaskan serta mengukur variabel laten Pemberayaan Zakat $\left(\mathrm{X}_{1}\right)$.

Nilai cross loading indikator $\mathrm{X}_{211}$ terhadap $\mathrm{X}_{2}$ sebesar 0,820; nilai cross loading $\mathrm{X}_{221}$ terhadap $\mathrm{X}_{2}$ sebesar 0,859; Nilai cross loading $\mathrm{X}_{231}$ terhadap $\mathrm{X}_{2}$ sebesar 0,832; Nilai cross loading $\mathrm{X}_{241}$ terhadap $\mathrm{X}_{2}$ sebesar 0,840; nilai cross loading indikator $\mathrm{X}_{242}$ terhadap $\mathrm{X}_{2}$ sebesar 0,814 lebih besar Nilai cross loading indikator $\mathrm{X}_{211}$ terhadap $\mathrm{X}_{3}$ sebesar -0,720; nilai cross loading $\mathrm{X}_{221}$ terhadap $\mathrm{X}_{3}$ sebesar -0,768; Nilai cross loading $\mathrm{X}_{231}$ terhadap $\mathrm{X}_{3}$ sebesar -0,820; Nilai cross loading $\mathrm{X}_{241}$ terhadap $\mathrm{X}_{3}$ sebesar $-0,865$; nilai cross loading indikator $\mathrm{X}_{242}$ terhadap $\mathrm{X}_{3}$ sebesar $-0,741$. Artinya indikator $X_{211}$ (dilaksanakannya perencanaan khusus program), $\mathrm{X}_{221}$ (waktu pengawasan), $\mathrm{X}_{231}$ (frekuensi pelaksanaan Evaluasi), $\mathrm{X}_{241}$ (jumlah tenaga pendamping), dan $\mathrm{X}_{242}$ (frekuensi kehadiran tenaga pendamping) valid dan dapat menjelaskan serta mengukur variabel laten Pengelolaan Zakat $\left(\mathrm{X}_{2}\right)$. 
Nilai cross loading indikator $\mathrm{X}_{311}$ terhadap $\mathrm{X}_{3}$ sebesar 0,854; Nilai cross loading $\mathrm{X}_{312}$ terhadap $\mathrm{X}_{3}$ sebesar 0,947 lebih besarNilai cross loading indikator $\mathrm{X}_{311}$ terhadap $\mathrm{X}_{3}$ sebesar -0,925; nilai cross loading $\mathrm{X}_{312}$ terhadap $\mathrm{X}_{3}$ sebesar 0,702. Artinya indikator X311 (Jumlah Modal kerja), indikator X312 (sarana produksi)valid dan dapat menjelaskan serta mengukur variabel laten $\mathrm{X}_{3}$ (Pendayagunaan Zakat).

Nilai cross loading indikator $Y_{111}$ terhadap Y sebesar 0,895; Nilai cross loading $\mathrm{X}_{312}$ terhadap $\mathrm{Y}$ sebesar 0,975 lebih besar dari Nilai cross loading indikator $\mathrm{Y}_{311}$ terhadap $\mathrm{X}_{3}$ sebesar -0,595; nilai cross loading $\mathrm{Y}_{312}$ terhadap $\mathrm{X}_{3}$ sebesar $-0,759$. Artinya indikator

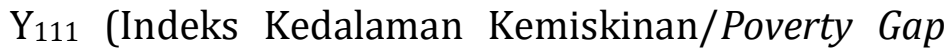
Index-P1), $\quad \mathrm{Y}_{112} \quad$ (Indeks Keparahan Kemiskinan/Proverty Severity Index-P2valid dan dapat menjelaskan serta mengukur variabel laten $\mathrm{X}_{3}$ (Pendayagunaan Zakat).

c) Average Variance Extracted (AVE).

Uji validatas Average Variance Extracted (AVE)dengan kriteria nilai $A V E$ yang diharapkan $>0,5$. Dari pertihungan didapat nilai $A V E$ sebagaimana ditunjukkan dalam tabel di bawah ini :

Tabel 6

Nilai Average Variance Extracted (AVE)

\begin{tabular}{|lc|c|}
\hline \multicolumn{2}{|c|}{ Variabel } & \multicolumn{2}{|c|}{$\begin{array}{c}\text { Average Variance Extracted } \\
\text { (AVE) }\end{array}$} \\
\hline $\begin{array}{l}\text { Pengelolaan Zakat } \\
\left(\mathrm{X}_{2}\right)\end{array}$ & & 0,694 \\
\hline
\end{tabular}

Sumber: Perhitungan Smart PLS 3.0 versi Student

Nilai AVE $\mathrm{X}_{1}$ (Pengelolaan Zakat)= 0,694 lebih besar 0,5 . Artinya variabel Pengelolaan Zakat valid.

2) Indikator Formatif 
Pengujian validitas indikator formatif menggunakan 2 (prosedur pengujian), yaitu pengujian Significance of weights dan Multicolliniyarity

a) Significance of weights

Pengujian Significance of weights dengan prosedur membandingkan antara nilai loading dengan standart. Kriteria pengujian nilai outer weghts kurang dari 0,05.

Tabel 7

Nilai Outer Weights

\begin{tabular}{|l|c|c|c|}
\hline $\begin{array}{c}\text { Indi- } \\
\text { kator }\end{array}$ & $\begin{array}{c}\mathrm{X}_{1-}- \\
\text { (Pemberdaya } \\
\text { an zakat) }\end{array}$ & $\begin{array}{c}\mathrm{X}_{3} \\
\text { (Pendayagunaan } \\
\text { zakat) }\end{array}$ & $\begin{array}{c}\mathrm{Y} \\
\text { (Penanggulang } \\
\text { an Kemiskinan }\end{array}$ \\
\hline $\mathrm{X}_{111}$ & 0,965 & & \\
\hline $\mathrm{X}_{121}$ & 0,042 & & \\
\hline $\mathrm{X}_{311}$ & & 0,418 & \\
\hline $\mathrm{X}_{312}$ & & 0,678 & 0,350 \\
\hline $\mathrm{Y}_{111}$ & & & 0,704 \\
\hline $\mathrm{Y}_{112}$ & & & \\
\hline
\end{tabular}

Sumber: Perhitungan Smart PLS 3.0

Mengacu pada tabel $7 \mathrm{di}$ atas dapat diketahui, nilai outer weight $\mathrm{X}_{111}=0,945$ lebih besar dari 0,500 . Nilai XX terhadap X1

1) Outer loading variabel laten $X_{1}$ dengan 2 (dua) indikator.

Nilai indikator $\mathrm{X}_{111}$ terhadap variabel laten $\mathrm{X}_{1}$ sebesar 1,000. Nilai tersebut telah memenuhi kriteria pengujian, yaitu nilai loading $\mathrm{X}_{111}=0,951$ lebih besar dari 0,5 sehingga indikator tersebut valid dan memiliki pengaruh terhadap variabel laten $\mathrm{X}_{1}$, artinya indikator jumlah rata-rata kenaikan pendapatan keluarga mustahiq/fakir miskin berpengaruh terhadap pemberdayaan zakat.

Nilai indikator $\mathrm{X}_{121}$ terhadap variabel laten $\mathrm{X}_{1}$ sebesar 0,839. Nilai tersebut telah memenuhi kriteria pengujian, yaitu nilai loading $\mathrm{X}_{121}=0,839$ 
lebih besar dari 0,5 sehingga indikator tersebut valid dan memiliki pengaruh terhadap variabel laten $\mathrm{X}_{1}$, artinya indikator jumlah rata-rata anggota keluarga mustahiq/fakir miskin yang mengalami kenaikan pendapatan berpengaruh terhadap pemberdayaan zakat.

2) Outer loading variabel laten $X_{3}$ dengan 3 indikator/variabel manifes

Nilai indikator $\mathrm{X}_{311}$ terhadap variabel laten $\mathrm{X}_{3}$ sebesar 0,857 . Nilai tersebut telah memenuhi kriteria pengujian, yaitu nilai loading $\mathrm{X}_{311}=0,857$ lebih besar dari 0,5 sehingga indikator tersebut valid dan memiliki pengaruh indikator terhadap variabel laten $\mathrm{X}_{3}$, artinya indikator jumlah modal kerja berpengaruh terhadap pendayagunaan zakat produktif kreatif.

Nilai indikator $\mathrm{X}_{312}$ terhadap variabel laten $\mathrm{X}_{3}$ sebesar 0,945. Nilai tersebut telah memenuhi kriteria pengujian, yaitu nilai loading $\mathrm{X}_{312}=0,945$ lebih besar dari 0,5 sehingga indikator tersebut valid dan memiliki pengaruh indikator terhadap variabel laten $X_{3}$, artinya indikator sarana produksi berpengaruh terhadap pendayagunaan zakat produktif kreatif.

3) Outer loading variabel laten $\mathrm{Y}_{1}$ dengan 2 (dua) indikator/variabel manifes

Nilai indikator $\mathrm{Y}_{111}$ terhadap variabel laten $\mathrm{Y}_{1}$ sebesar 0,857 . Nilai tersebut telah memenuhi kriteria pengujian, yaitu nilai loading $\mathrm{Y}_{111}=0,857$ lebih besar dari 0,5 sehingga indikator tersebut valid dan memiliki pengaruh indikator terhadap variabel laten $\mathrm{Y}_{1}$, artinya indikator Indeks Kedalaman Kemiskinan/Poverty Gap Index-P1 mengukur dengan benar dan tepat penanggulangan kemiskinan.

Nilai indikator $\mathrm{Y}_{121}$ terhadap variabel laten $\mathrm{Y}_{1}$ sebesar 0,945. Nilai tersebut telah memenuhi 
kriteria pengujian, yaitu nilai loading $\mathrm{Y}_{121}=0,945$ lebih besar dari 0,5 sehingga indikator tersebut valid dan memiliki pengaruh indikator terhadap variabel laten $\mathrm{Y}_{1}$,artinya indikator Indeks Keparahan Kemiskinan/Proverty Severity IndexP2 mengukur dengan benar dan tepat penanggulangan kemiskinan.

b) Variance Inflation Factor (VIP)

Nilai VIF digunakan untuk menguji hubungan antar indikator, apakah indikator formatif mengalami multicolliniyarity atau tidak. Kriteria pengujian nilai VIF antara 5 - 10 indikator tersebut mengalami multicolliniyarity. Pengujian multikolinieritas dapat pula menggunakan kriteria nilai $V I F<3,33$.

Tabel 8

Collinyarity Statisic (VIF)

\begin{tabular}{|l|l|l|}
\hline \multicolumn{1}{|c|}{ Variabel } & \multicolumn{1}{|c|}{ Indikator } & \multicolumn{1}{c|}{ VIP } \\
\hline $\mathrm{X}_{1}$ (Pemberdayaan & $\mathrm{X}_{111}$ & 3,169 \\
\cline { 2 - 3 } Zakat) & $\mathrm{X}_{121}$ & 3,169 \\
\hline $\mathrm{X}_{3}$ (Pendayagunaan & $\mathrm{X}_{311}$ & 1,704 \\
\cline { 2 - 3 } Zakat) & $\mathrm{X}_{312}$ & 1,704 \\
\hline $\mathrm{Y}$ (Penanggulangan & $\mathrm{Y}_{111}$ & 2,491 \\
\cline { 2 - 3 } Kemiskinan) & $\mathrm{Y}_{112}$ & 2,491 \\
\hline
\end{tabular}

Sumber: Perhitungan Smart PLS 3.0 Student Version

Hasil pengujian VIF menggunakan SmartPLS 3 Student Version, sebagaimana tabel $4.5 \mathrm{di}$ atas, bahwa nilai indikator formatif $\mathrm{X}_{111}, \mathrm{X}_{121}, \mathrm{X}_{311}, \mathrm{X}_{112}$, $\mathrm{Y}_{111}, \mathrm{Y}_{112}$ nilainya di luar $\mathbf{5} \mathbf{- 1 0}$ atau kurang dari 3,3. Artinya tidak terjadi multikoliner antar indikator, sehingga seluruh indikator valid.

b. Uji reliabilitas

Pengujian reliabilitas indikator reflektif dan formatif menggunakan uji CompositeReliability dan Cronbach Alpha.

1) Composite Reliability

Composite reliability digunakan untuk mengetahui ryabilitas pengukuran indikator terhadap konstruk. Uji 
ini dengan cara membandingkan antara nilai composite reliability dengan nilai pembanding $=0,7$. Kriteria pengujian, reliabel apabila nilai perhituhangan composite reliability> 0,7. Menggunakan Smart PLS 3 Studentversion didapat nilai composite reliability, sebagaimana tabel 4.6 berikut:

Tabel 9

Nilai Composite Reliability

\begin{tabular}{|c|c|}
\hline $\begin{array}{c}\text { Variabel (Construct } \\
\text { Reliability and Validity) }\end{array}$ & $\begin{array}{c}\text { Composite } \\
\text { Reliability }\end{array}$ \\
\hline $\mathrm{X}_{2}$ (Pengelolaan Zakat) & 0,919 \\
\hline
\end{tabular}

Sumber: Perhitungan Smart PLS 3.0

Nilai Composite reliability Variabel Y (Penanggulangan Kemiskinan $)=0,919>0,7$ Jadi seluruh variabel memiliki nilai lebih besar 0,7 , maka indikator setiap konstruk variabel reliabel.

2) Cronbach Alpha

Uji reliabilitas dengan menggunakan Cronbach Alpha untuk memperkuat uji ryalibilitas, digunakan uji ini. Kriteria pengujian dengan nilai Cronbach's Alpha > 0,6. Menggunakan sofware Smart PLS 3 Student Version, didapatkannilai untuk semua konstruk> 0,6. Lebih lengkapnya pada tabel 4.7 di bawah ini.

Tabel 10

Nilai Cronbach's Alpha

\begin{tabular}{|c|r|}
\hline $\begin{array}{c}\text { Variabel (Construct } \\
\text { Reliability and Validity) }\end{array}$ & Cronbach's Alpha \\
\hline Pengelolaan Zakat $\left(\mathrm{X}_{2}\right)$ & 0,890 \\
\hline
\end{tabular}

Sumber: Perhitungan Smart PLS 3.0

Nilai $\mathrm{X}_{1}$ (Pengelolaan Zakat) $=0,890>0,6$, artinya variabel $X_{1}$ (Pengelolaan Zakat) reliabel.

2. Inner model

Analisa inner model dilakukan untuk memastikan bahwa model struktural yang dibangun adalah akurat. Evaluasi inner model dapat dilihat dari beberapa indikator yang meliputi: 
a. Koefisien Determinasi (R-Squares/ $\mathrm{R}^{2}$ )

Nilai $\mathrm{R}^{2}$ merupakan uji goodness fit model. Prosedur pengujian koefisien determinasi dengan cara membandingkan antara nilai $\mathrm{R}^{2}$ hitung bootstrapping dengan nilai standar. Katetori penilaian adalah $\mathrm{R}^{2}=0,67$

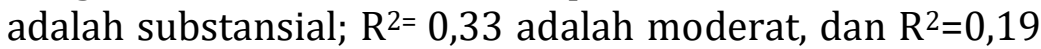
adalah lemah, dan nilai $\mathrm{R}^{2}>0,7$ kategori kuat 25 semakin besar nilai $\mathrm{R}^{2}$, maka semakin besar kemampuan variabel independen dapat menjelaskan variabel dependen, dengan demikian persamaan struktural semakin baik.

Dari perhitungan Smart PLS 3 Student version seperti tabel di bawah ini:

Tabel 11

Nilai R-Square $\left(\mathrm{R}^{2}\right)$

\begin{tabular}{|l|r|}
\hline \multicolumn{1}{|c|}{ Variabel } & \multicolumn{1}{|c|}{$\begin{array}{c}\mathrm{R}^{2} \text { (Original } \\
\text { Sample) }\end{array}$} \\
\hline $\mathrm{X}_{1}$ (Pemberdayaan zakat) & 0,694 \\
\hline $\mathrm{X}_{2}$ (Pendayagunaan zakat) & 0,883 \\
\hline $\mathrm{Y}$ (Penanggulangan Kemiskinan) & 0,928 \\
\hline
\end{tabular}

Sumber: Perhitungan Smart PLS 3.0 Student Version

Nilai $\mathrm{R}^{2}$ Variabel $\mathrm{X}_{1}=0,694>0,67$. Artinya variabel pengelolaan zakat dapat memprediksikan atau menjelaskan variabel pemberdayaan zakat sebesar 69,4\% sedangkan sisanya sebesar $30,6 \%$ diprediksi atau variabel lain yang tidak diteliti. Nilai $\mathrm{R}^{2}$ Variabel $\mathrm{X}_{1}=$ $0,883>0,7$. Artinya variabel pengelolaan zakat dapat memprediksikan atau menjelaskan variabel pendayagunaan zakat sebesar $88,3 \%$ sedangkan sisanya sebesar $11,7 \%$ diprediksi atau variabel lain yang tidak diteliti. Nilai $\mathrm{R}^{2}$ Variabel $\mathrm{Y}=0,928>0,7$. Artinya variabel pengelolaan zakat dan variabel pendayagunaan zakat dapat memprediksikan atau menjelaskan variabel penanggulangan kemiskinan sebesar 92,8\% sedangkan

25 Jonathan Sarwono and Umi Narimawati, Membuat Skripsi, Tesis, Dan Disertasi Dengan Partial Lyast Square SEM (PLS-SEM) (Yogyakarta: CV. Andi Offset, 2015).23 
sisanya sebesar 7,2\% diprediksi atau variabel lain yang tidak diteliti.

b. Predective Relevance $\left(\mathrm{Q}^{2}\right)$

Predective Relevance $\left(Q^{2}\right)$ untuk menilai variabel laten endogen sebagai kekuatan prediksi dari model struktural. Nilai R-Squares merupakan uji goodness fit model, dirumuskan $\mathbf{Q}^{\mathbf{2}}=\mathbf{1}-\left[\left(\mathbf{1}-\mathbf{R}_{\mathbf{1}}{ }^{\mathbf{2}}\right)\left(\mathbf{1}-\mathbf{R}_{\mathbf{2}}{ }^{2}\right)\left(\mathbf{1}-\mathbf{R}_{\mathbf{3}}{ }^{2}\right)\right.$. Kriteria goodness fit modelmenyatakan model struktural menuhi syarat apabila nilai $\mathrm{Q}^{2}>0,5$. Dari perhitungan Smart PLS 3 Student Version sebagaimana tabel 4.8 di atas, maka: $\mathrm{Q}^{2}=$ $1-\left[1-\left(1-0,694^{2}\right)\left(1-0,883^{2}\right)\left(1-0,928^{2}\right)\right]=0,984$ (Artinya model memeliki relevansi prediktif.)

c. Goodness of Fit Index (GoF)

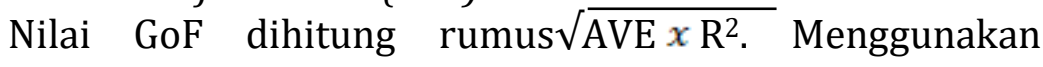

SmartPLS 3 Student Version diketahui nilai AVE $=0,694$; Nilai $\mathrm{R}_{1}^{2}=0,694, \mathrm{R}_{2}^{2}=0,833, \mathrm{R}_{3}{ }^{2}=0,928$. Diperoleh nilai GoF sebesar 0,761 masuk.

Jadi dari hasil pengujian $\mathrm{R}^{2}$ (R-Squares) , $Q^{2}$ (Predective Relevance) dan GoF(Goodness of Fit Index) terlihat bahwa model yang dibentuk adalah robust, sehingga pengujian hipotesa dapat dilakukan

3. Pengujian Hipotesis

Prosedur pengujian hipotesis dengan cara membandingkan antara nilai t-statistik dan nilai probabilitas pada $\alpha$ (alpha)= $5 \%$. Nila $t-\alpha$ pada DF $5 \%=1,96$. Kriteria penerimaan atau penolakan hipotesa adalah sebagai berikut:

a. $\mathrm{H}_{1}$ diterima dan $\mathrm{H}_{0}$ ditolak,jika t-statistik $>1,96$.

b. $\mathrm{H}_{1}$ ditolak dan $\mathrm{H}_{0}$ diterima, jika t-statistik $<1,96$ Hasil perhitungan dengan Smart PLS 3 Student Version diketahui hasil t-statistik dan p sebagai berikut:

Tabel 12

Perhitungan Nilai t-statistik dan Nilai Probabilitas pada DF 5\%

\begin{tabular}{|l|r|r|}
\hline Path Coefficients & $\begin{array}{l}\text { T-statistics } \\
\text { (IO/STDEVI) }\end{array}$ & $\begin{array}{l}\text { P- } \\
\text { values }\end{array}$ \\
\hline $\begin{array}{l}\mathrm{X}_{1} \text { (Pemberdayaan zakat)=> Y } \\
\text { (Penanggulangan Kemiskinan) }\end{array}$ & 15,757 & 0,000 \\
\hline $\mathrm{X}_{2}$ (Pengelolaan zakat)=> $\mathrm{X}_{1}$ & 19,637 & 0,000 \\
\hline
\end{tabular}




\begin{tabular}{|l|r|r|}
\hline (Pemberdayaan zakat) & & \\
\hline $\begin{array}{l}\mathrm{X}_{2} \text { (Pengelolaan zakat)=> } \mathrm{X}_{3} \\
\text { (Pendayagunaan Zakat) }\end{array}$ & 43,159 & 0,000 \\
\hline $\begin{array}{l}\mathrm{X}_{3} \text { (Pendayagunaan zakat)=> Y } \\
\text { (Penanggulangan Kemiskinan) }\end{array}$ & 0,249 & 0,803 \\
\hline
\end{tabular}

Sumber: Perhitungan Smart PLS 3.0 versi student

Menggunakan prosedur dan kriteria pengujian di atas, maka hipotesa spesifik-masing-masing konstruk sebagai berikut:

1. Dari perhitungan Smart PLS 3 Student Version sebagaimana tabel 12 di atas di dapat nilai t-statistik=15,757>t- $\alpha=1,96$ maka $\mathrm{H}_{1}$ diterima $\mathrm{H}_{0}$ ditolak, artinya Variabel laten $\mathrm{X}_{1}$ (Pemberdayaan Zakat), berpengaruh terhadap variabel laten Y (Penanggulangan Kemiskinan di Propinsi Jawa Timur).

2. Dari perhitungan menggunakan Smart PLS 3 Student Version sebagaimana tabel 12 dapat nilai t-statistik $=19,637>\mathrm{t}-\alpha$ $=1,96$ maka $\mathrm{H}_{1}$ Diterima, artinya variabel laten $\mathrm{X}_{1}$ (Pemberdayaan Zakat) berpengaruh signifikan terhadap variabel laten pemberdayaan zakat.

3. Dari perhitungan menggunakan Smart PLS 3 Student Version sebagaimana tabel 12 didapat nilai t-statistik $=12,791>\mathrm{t}-\alpha$ =1,96 maka $\mathrm{H}_{1}$ diterimadan $\mathrm{H}_{0}$ ditolak, artinya variabel $\mathrm{X}_{2}$ (Pengelolaan Zakat) melalui variabel laten $\mathrm{X}_{1}$ (Pemberdayaan Zakat) berpengaruh signifikan terhadap $\mathrm{Y}$ (Penanggulangan Kemiskinan di Propinsi Jawa Timur).

4. Dari perhitungan menggunakan Smart PLS 3 Student Version sebagaimana tabel 12 dapat nilai t-statistik $=43,159>\mathrm{t}-\alpha$ =1,96 maka $\mathrm{H}_{1}$ diterima dan $\mathrm{H}_{0}$ ditolak, artinya variabel laten $\mathrm{X}_{2}$ (Pengelolaan Zakat) berpengaruh positif dan signifikan terhadap variabel laten $\mathrm{X}_{3}$ (Pendayagunaan Zakat). Menggunakan Smart PLS 3 Student Version sebagaimana tabel 4.10 di atas nilai $\mathrm{p}=0,000<0,05$ maka $\mathrm{H}_{1}$ diterima dan $\mathrm{H}_{0}$ ditolak, artinyaVariabel laten $\mathrm{X}_{2}$ (Pengelolaan Zakat) tidak berpengaruh terhadap variabel laten $\mathrm{X}_{3}$ (Pendayagunaan Zakat).

5. Dari perhitungan menggunakan aplikasi Smart PLS 3 Student Version sebagaimana tabel 12 di atas di dapat nilai t- 
statistik $=0,246<\mathrm{t}-\alpha=1,96$ maka $\mathrm{H}_{1}$ ditolakdan $\mathrm{H}_{0}$ diterima, artinyaVariabel laten $\mathrm{X}_{3}$ (Pendayagunaan Zakat) tidak berpengaruh terhadap variabel laten $\mathrm{Y}$ (Penanggulangan Kemiskinan).

6. Dari perhitungan menggunakan Smart PLS 3 Student Version sebagaimana tabel 12 di atas di dapat nilai t-statistik= $0,230<\mathrm{t}-\alpha=1,96$ maka $\mathrm{H}_{1}$ ditolakdan $\mathrm{H}_{0}$ diterima, artinyaVariabel laten $\mathrm{X}_{2}$ (Pengelolaan Zakat) melalui variabel $\mathrm{X}_{3}$ (Pendayagunaan Zakat) tidak berpengaruh terhadap variabel laten Y (Penanggulangan Kemiskinan).

\section{Analisa Data Kualitatif Dan Intepretasi Hasil}

Pemberdayaan Zakat berpengaruh terhadap Penanggulangan Kemiskinan. Komunitas yang berhasil mengembangkan program Pemberdayaan Ekonomi Kota di Sidoarjo. Penanggulangan kemiskinan di komunitas Sidoarjo ditandai dengan dana bantuan pinjaman modal usaha yang diterima komunitas berkembang dari dana awal yang diterima komunitas. Perkembangan dana diperoleh dari perputaran pinjaman modal ke anggota. Anggota mengembalikan angsuran pinjaman pokok dan ditambah infaq dengan nilai yang tidak mengikat. Dari temuan di lapanganbesaran infaq yang dibayarkan anggota kepada komunitas tidak selalu sama setiap bulannya, akan tetapi setiap bulan rutin membayar. Nilai infaq yang dibayarkan anggota komunitas di kisaran antara Rp.10.000,00-Rp.25.000,00 per orang per bulan. Temuan di lapangan di komunitas Sidoarjo, penanggulangan kemiskinan ditandai dengan berperannya komunitas yang didampingi YDSF. Komunitas kemudian telah menjadi mandiri membentuk badan hukum dan telah melepaskan diri dari pendampinganYDSF. Pelepasan peran YDSF diindikasikan dari penyerahan bantuan pinjaman modal usaha komunitas menjadi modal komunitas, bukan lagi modal yang harus dikembalikan kepada YDSF. Keberhasilan komunitas membantu mengentaskan kemiskinan anggotanya tidak lepas dari peran dan fungsi komunitas yang memberikan layanan bantuan pinjaman modal usaha lanjutan, layanan konsultasi usaha, layanan peningkatan motivasi usaha dan spiritual anggota. 
Peningkatan pendapatan anggota komunitas rata-rata telah di atas garis kemiskinan di Provinsi Jawa Timur tahun 2017.

Pengelolaan zakat berpengaruh terhadap pemberdayaaan zakat. Pengelolaan zakat di Program Pemberdayaan Ekonomi Kota diselenggarakan melalui tahapan-tahapan. Tahapan dimulai dari identifikasi. Identifikasi dengan melakukan survei dan mapping. Dilanjutkan dengan perencanaan, di tahap ini fase yang sangat menentukan keberhasilan program. Pada tahap perencanaan dilakukan analisa hasil survei dan mapping yang menjadi dasar program akan dilaksanakan oleh YDSF di komunitas yang mengajukan proposal tersebut atau tidak. Setelah proposal disetujui, proses pengelolaan yang dilakukan oleh YDSF di Program Pemberdayaan Ekonomi Kota adalah fase pelaksanaan pada fase ini kegiatan yang dilakukan oleh YDSF adalah melakukan pendampingan, pembinaan, pengawasan. Pembinaan yang dilakukan oleh YDSF tampak menonjol dibandingkan dengan kegiatan-kegiatan pengawasan dan pendampingan. Kegiatan pembinaan dilaksanakan dengan memberikan pelatihanpelatihan kepada komunitas. Materi pelatihan yang diberikan sesuai dengan usulan komunitas, dan materi pelatihan yang telah disiapkan oleh YDSF. Kegiatan pembinaan, demikian, belum diikuti dengan kegiatan pendampingan dan pengawasan dengan yang konsisten. Di awal-awal program pengawasan dilakukan dengan baik, dengan cara petugas YDSF langsung datang ke lokasi program setiap 1 (satu) minggu sekali, namun setelah program berjalan 3 (tiga) bulan petugas YDSF tidak datang ke komunitas. Namun kelemahan pengawasan tertutup dengan baik dengan kegiatan pembinaan di atas. Contoh di Komunitas Surabaya, anggota komunitas memanfaatkan hasil pelatihan dengan membuat usaha-usaha baru seperti salah satu anggota mendirikan usaha jasa service $A C$. Keberdayaan anggota komunitas diikuti juga dengan kemandirian komunitas. Komunitas bermetamorfosa menjadi koperasi Shariah. Koperasi berfungsi menjadi lembaga penyedia jasa pembiayaan dan penyimpanan dana bagi anggota komunitas, serta memberikan layanan konsultasi bisnis, menerima 
pembayaran infaq anggota. Walaupun demikian ada tantangan lain dalam pengelolaan zakat di YDSF yaitu peran pendampingan. Pendampingan telah dilakukan dengan kontinyu, namun YDSF belum mempunyai tenaga khusus yang memiliki keahlian dibidang pemberdayaan bahkan acap kali penanggung jawab program yang melakukan pendampingan lansung. Selain itu, waktu pendampingan yang dilakukan tidak rutin dengan pendekatan pasif, dimana pendamping masih menunggu permintaan dari komunitas, dengan waktu yang tidak tentu.

Temuan di lapangan, pengelolaan zakat dilakukan dengan dengan pola pemberdayaan zakat dengan cara menyalurkan bantuan pinjaman modal usaha, dana yang salurkan hanya boleh untuk kegiatan usaha tidak boleh di luar usaha seperti membeli sembako, atau barang-barang lainnya di luar usaha. Penyaluran bantuan pinjaman modal usaha diikuti dengan pembinaan, pendampingan, pengawasan. Dengan pola tersebut, temuan di lapangan menunjukkan pengelolaan zakat dengan cara melakukan identifikasi, melakukan mapping dan survei memastikan kelayakan komunitas berpengaruh terhadap program Pemberdayaan Ekonomi Kota. Pemberdayaan zakat diindikasikan dengan temuan di lapangan bahwa jumlah modal usaha kelompok yang telah mandiri dan mengalami peningkatan, rata-rata peningkatan 8\%-10\% per tahun pinjaman modal usaha kepada komunitas. Jumlah pinjaman macet kurang dari 2\% bahkan terdapatkomunitas mandiri yang tingkat kemacetan $0 \%$ selama 4 (empat) tahun. Terdapat peningkatan pinjaman yang diajukan oleh anggota ke komunitas dari yang sebelumnya rata-rata Rp.1.000.000,00 di tahun pertama, menjadi Rp.1.200.000,00-Rp.1.500.000,00 per orang di tahun kedua.Pembedayaan zakat yang demikian berpengaruh terhadap peningkatan pendapatan anggota komunitas dengan indikasi, anggota membayar infaq, dan pendapatan anggota telah naik di atas garis kemiskinan Propinsi Jawa Timur Jawa Timur, dan naik di atas pendapatan 
sebelumnya. Jika dibandingkan dengan pendapatan sebelumnya kenaikannya sebesar 25\%-45\%.2627

Pengelolaan Zakat berpengaruh terhadap Pendayagunaan Zakat. YDSF. Pendayagunaan zakat yang dilakukan oleh YDSF dalam program Pemberdayaan Ekonomi Kota fokus kepada penyaluran dana bantuan pinjaman modal usaha dan memberikan pelatihan-pelatihan yang mendukung usaha komunitas, serta memberikan sarana prasarana usaha komunitas. Temuan di lapangan komunitas yang telah mandiri, anggotanya menggunakan dana bantuan pinjaman modal usaha untuk membuka usaha atau untuk menambah kapasitas usaha yang sudah ada, sedangkan sarana prasarana yang diterima digunakan untuk memperbaiki kualitas produksi dan layanan usaha. Seperti bantuan sarana prasarana yang diterima komunitas PKL berupa gerobak. Komunitas PKL juga mendapatkan pelatihan-pelatihan kuliner dan pembuatan penganan. Keberhasilan pengelolaan zakat terhadap pendayagunaan zakat ditandai pula dengan alokasi dana yang relatif kecil pada program Pemberdayaan Ekonomi Kota tetapi tetap memberikan pengaruh positif pada komunitas-komunitas tertentu seperti di Surabaya dan Sidoarjo. Pengaruh positif tersebut karena pengelolaan zakat dilakukan dengan melakukan pengawasan, pendampingan dan pembinaanpembinaan kepada komunitas. Namun demikian, terdapat kelamahan pada pengelolaan zakat, pengawasan yang kurang ajeg, pendampingn yang pasif dan terputus (tidak rutin dan tidak terjadwal) serta pembinaan hanya berbentuk pelahitanpelatihan, sehingga dibeberapa komunitas yang memiliki kareteristik keras, tidak mau mengikuti aturan program menjadi tantangan, seperti di komunitas Pemulung di Makam Rangkah Surabaya ${ }^{28}$.

${ }^{26}$ Data primer diolah

${ }^{27}$ Peneliti, Pengamatan, Surabaya, 23 Nopember 2017.

${ }^{28}$ Rokhmad Hidayat, Wawancara Mendalam, Surabaya, 20 Nopember 2017. 
Pendayagunaan zakat tidak berpengaruh terhadap penanggulangan kemiskinan di Propinsi Jawa Timur. YDSF melakukan pendayagunaan zakat melalui program pendidikan, dakwah, ekonomi dan nilai bantuan program. Ketidak mampuan pendayagunaan zakat menanggulangi kemiskinan, karena salah satu temuan penelitian adalah alokasi dana program Pemberdayaan Ekonomi "hanya" sebesar Rp.400.000.000,00 atau 1,21\% dari total dana program YDSF.YDSF melalui Program Pemberdayaan Ekonomi Kota bertujuan meningkatkan pendapatan menjadikan mustahiq menjadi muzaki, artinya kelompok pemulung dapat keluar dari garis kemiskinan.

Untuk itu desain program Pemberdayaan Ekonomi Kota adalah meningkatkan usaha komunitas atau membuka usaha baru bagi anggota komunitas. Seperti pemulung diajak untuk membuka usaha baru, atau mengembangkan usahanya dengan menjadi pengusaha rosokan. Contoh lain pinjaman modal usaha yang diberikan YDSF kepada komunitas di Putat Jaya dan Gubeng kurang lebih lebih "hanya" Rp.400.000,00, dana tersebut belum cukup untuk membuka usaha baru atau mengembangkan usaha, kebutuhan dana untuk mengembangkan usaha kuliner, sebagai modal kerja minimal Rp.1.200.000,00. Sedangkan permasalahan yang dialami oleh mustahiq adalah ketidakmampuan memenuhi kebutuhan pokok sehari-hari secara berkelanjutan. Tingkat pendapatan yang tidak pasti atau naik turun secara drastis terutama di komunitas seperti pemulung. Rata-rata tingkat pendapatan yang diterima kelompok pemulung di bawah angka garis kemiskinan Propinsi Jawa Timur.

Mengacu kepada tingkat pendapatan yang layak dengan melihat UMK di kota Surabaya, Sidoarjo, dan Gresik, pendapatan komunitas pemulung sangat jauh dari layak. Upah minimun di 3 (tiga) kota tersebut di atas Rp.3.000.000,00 atau tepatnya Surabaya upah minimun tahun 2016 Rp.3.045.000,00/bulan, Sidoarjo Rp.3.040.000,00/bulan, dan 
Gresik Rp.3.042.000,00.29 Upah minimun tersebut sebagai acuan pemenuhan kebutuhan hidup yang layak bagi orang yang hidup di kota tersebut. Dari temuan data, pendapatan anggota komunitas yang gagal bina (komuntas pemulung/pemulung), per bulan kurang dari Rp.1.950.000,00. Sedangkan keperluan hidup sehari-hari untuk memenuhi kebutuhan keluarga lebih dari Rp.2.000.000,00, sehingga mereka untuk menutup kebutuhan dengan hutang atau menunggu bantuan dari pemerintah. Temuan di lapangan bahwa dana bantuan pinjaman modal usaha yang dirasa tidak cukup untuk membuka usaha atau mengembangkan usaha, maka oleh penerima manfaat untuk menutup kebutuhan hidup seharihari.

Namun seperti temuan di atas kebutuhan modal usaha yang dibutuhkan anggota komunitas tidak mencukupi, maka dampaknya justrudana tersebut tidak dipergunakan untuk membuka usaha tetapi untuk kebutuhan konsumtif. Jadi faktor yangberkontribusi pada pengelolaan zakat melalui pendayagunaan zakat tidak berpengaruh kepada penanggulangan kemiskinan adalah salah satunya adalah alokasi dana program Pemberdayaan Ekonomi Kota yang relatif kecil, "hanya" Rp.400.000.000,00 atau 1,21\% dari total dana program YDSF Rp.33.000.000.000,00, karakter anggota komuntas, dan keberadaan tokoh penggerak atau panutan yang "baik" yang di hormati oleh anggota komunitas.

\section{Penutup}

Kesimpulan penilitian adalah Pemberdayaan zakat berpengaruh positif dan siginifikan sebesar 15,757 terhadap penanggulangan kemiskinan. Pengelolaan zakat berpengaruh positif dan siginifikan sebesar 19,637 terhadap pemberdayaaan zakat. Pengelolaan zakat melalui pendayagunaan zakat berpengaruh positif sebesar 12,791 terhadap penanggulangan kemiskinan. Pengelolaan zakat berpengaruh positif dan

\footnotetext{
${ }^{29}$ Egidius Patnistik, "Gubernur Jatim Tetapkan UMK 2016," www.regional.kompas.com .2
} 
siginifikan sebesar 43,159 terhadap pendayagunaan zakat. Pendayagunaan zakat tidak berpengaruh terhadap penanggulangan kemiskinan. Serta pengelolaan zakat melalui pendayagunaan zakat tidak berpengaruh terhadap penanggulangan Kemiskinan.

Pengelolaan zakat Program Pemberdayaan Ekonomi Zakat melalui perencanaan, pengawasan, evaluasi dan pendampingan. Pemberdayaan zakat diketahui dari status mustahiq menjadi muzaki. Pendayagunaan zakat dengan memberikan bantuan modal kerja dan bantuan pelatihanpelatihan serta sarana produksi melalui kelompok.

\section{Daftar Pustaka}

Analisa, Nadiya. "Pengaruh Pendayagunaan Zakat Produktif Terhadap Pendapatan Mustahiq (Studi Kasus Pada LAZ PKPU Cabang Surabaya).” UIN Walisongo Semarang, 2015.

Badan Kebijakan Fiskal Pusat Kebijakan Ekonomi Makro Kementerian Keuangan Republik Indonesia. Laporan Kajian Islamic Public Finance. Jakarta: Kementerian Keuangan Republik Indonesia, 2012.

Badan pusat statistik. "Data Penduduk Muslim." Kemenag Jatim.

-_- "Jumlah Dan Presentase Penduduk Miskin, Garis Kemiskinan, Indeks Kedalaman Kemiskinan (P1) Indeks Keparahan Kemiskinan (P2) Menurut Provinsi." http://www.bps.go.id/linkTabelStatis/view/id/1488.

_—_. "Kependudukan." BPS Jatim.

___. "Zakat Indonesia Yang Terhimpun Baru Satu Persen Dari Potensi." http://www.nasional.kompas.com/read/2016/07/02/10 000301/zakat.indonesia.yang.terhimpun.baru.satu.persen. dari.potensi.

Dwiharjo, Untung. "Menguak Potensi Zakat Di Jawa Timur." http://www.ydsf.org/blog/menguak-potensi-zakat-dijawa-timur. 
- _- "Potensi Zakat Di Indonesia Sangat Besar." http://www.ksp.go.id/potensi-zakat-di-indonesia-sangatbesar/.

Mannan, Muhammad Abdullah. Teori Dan Praktik Ekonomi Islam. Yogyakarta: PT. Dana Bhakti Wakaf, 1995.

Mubarok, Abdullah, and Baihaqi Fanani. "Penghimpunan Dana Zakat Nasional (Potensi, Realisasi Dan Peran Penting Organisasi Pengelola Zakat)" (n.d.).

Muda, Noor Syafinas Binti. Keberkesanan Tagihan Zakat Kepada Asnaf Fakir Dan Miskin: Kajian Kes Bantuan Jayadiri, Jabatan Zakat Negeri Kedah. Ogos, 2014.

Mutia, Agustina, and Anzu Elvira Zahara. "Analisis FaktorFaktor Yang Mempengaruhi Kesejahteraan Ekonomi Mustahiq Melalui Pemberdayaan Zakat (Studi Kasus PenyaluranZakat Produktif/ Modal Usaha Pada Bazda Kota Jambi)." Kontekstualita Vol.25 No. (n.d.):

Nabani, Taqiyuddin. Al Nidlam Al Iqtishadi Fi Al Islam Islam (Membangun Sistem Ekonomi Altematif: Perspektif Islam), Terj. Maghfur Wahid. Surabaya: Risalah Gusti, 1999.

Patnistik, Egidius. "Gubernur Jatim Tetapkan UMK 2016." www.regional.kompas.com .

Pogo, Tajuddin. "Distribusi Kekayaan Individu Dalam Ekonomi Islam." UIN Syarif Hidayatullah, 2010.

Republika.co.id. "Inilah 10 Negara Dengan Populasi Muslim Terbesar

Di

Dunia."

http://m.republika.co.id/berita/dunia-islam/islamnusantara/15/05/27/nowyh5-inilah-10-negara-denganpopulasi-muslim-terbesar-di-dunia,.

Rusli. "Analisis Dampak Pemberian Modal Zakat Produktif Terhadap Pengentasan Kemiskinan Di Kabupatenaceh Utara." Jurnal Ilmu Ekonomi ISSN 2302-, no. Pascasarjana Universitas Syiah Kuala 8 Pages pp (n.d.):

Saifulloh. "Pengelolaan Zakat Dalam Pemberdayaan Masyarakat 
Pengaruh Variabel Moderator Pemberdayaan Dan Pendayagunaan Zakat ...

(Studi Pada LAZ Rumah Zakat Kota Semarang)." UIN Walisongo Semarang, 2014.

Sartika, Mila. "Pengaruh Pendayagunaan Zakat Produktif Terhadap Pemberdayaan Mustahiq Pada LAZ Yayasan Solo Peduli Surakarta." Jurnal Ekonomi Islam La Riba Vol.II No. (2008).

Sarwono, Jonathan, and Umi Narimawati. Membuat Skripsi, Tesis, Dan Disertasi Dengan Partial Lyast Square SEM (PLSSEM). Yogyakarta: CV. Andi Offset, 2015.

Sugiyo. Metode Penelitian Kombinasi (Mix Methods). Bandung: Alfabeta, 2017.

Zuraya, Nidia. "Potensi Zakat Rp 217 Triliun Terserap Satu Persen."

http://www.republika.co.id/berita/ekonomi/syariahekonomi/13/04/29/mm039y-potensi-zakat-rp-217triliun-terserap-satu-persen.

Rokhmad Hidayat, "wawancara", mendalam, Surabaya 20 November 2017

Peneliti pengamatan, Surabaya Tgl 23 November 2017 